International Journal of English Literature and Social Sciences
Vol-6, Issue-2; Mar-Apr, 2021
Journal Home Page Available: https://ijels.com/
Journal DOI: $10.22161 /$ ijels

\title{
Dystopia as a subversion of Utopia: Upamanyu Chatterjee's Novels
}

\author{
Adithi Shastry Kallaje
}

Research Scholar, Department of English, Mangalore University, Mangalagangotri, India

Received: 18 Jan 2021; Received in revised form: 19 Mar 2021; Accepted: 03 Apr 2021; Available online: 27 Apr 2021

C2021 The Author(s). Published by Infogain Publication. This is an open access article under the CC BY license

(https://creativecommons.org/licenses/by/4.0/).

\begin{abstract}
Resistance to a Utopian world is often seen in most of the works in Modern fiction. The complicated relationship between the ideal and the real becomes a source of argument for and against the genre Utopia or even Dystopia. In the recent times one can find a rise in the publication of dystopian novels. Although there is evidence to prove that it is a twentieth-century phenomenon, it is interesting that the genre seems to grow stronger day after day. This article explores dystopia as a subversion of Utopia in the selected novels of Upamanyu Chatterjee, The English August: An Indian Story, The Mammaries of the Welfare State, The Last Burden, Way to Go, Weight Loss.
\end{abstract}

Keywords - Dystopia, Utopia, Decadence, degeneration, alienation

\section{INTRODUCTION}

Utopias remain a topological portrayal of another spacetime, and utopian works are a discussion and portrayal of the determined and standardized version of a social paragon. (Dvorak, 1999, p. 73) The conception of Utopia incurs its course from Thomas More's Utopia (1516). The work envisions a far fledged site and which is almost unimaginable in reality. But its antonym, Dystopia, depicts a gloomy and a disturbing future. It envisions cataclysmic end of the world as we know. This paper explores if whether the dystopian mode could be devised to depict the inconsistencies of the world. Can dystopia be a subversion of utopia? This article explores this perspective to find an answer using references to the selected novels of Upamanyu Chatterjee. As dystopia emerges as a predominant feature in most of Upamanyu Chatterjee's fiction, the study will explore the representations that communicate dystopia through decadence, degeneration and alienation. The study explores the elements of decadence, degeneration that potentially subverts the notion of an 'ideal' or Utopia in the novels of Upamanyu Chatterjee.

\section{DISCUSSION}

Literary dystopia finds its expression as a 'speculation' of the future. Most of the literary dystopias represent the eventual collapse of society in the vogue of fascists and totalitarian governments that take total control over the citizens. Dystopia features an authoritarian regime that aims to infringe on the freedom of an individual. During my research $\mathrm{I}$ found that most of the known literary dystopia can be found in the works of George Orwell, Aldous Huxley, Margaret Atwood, and Anthony Burges. Although there are many works, I shall state only a few here for reference. George Orwell's Nineteen Eighty-Four commonly occurs with the famous lines "Big Brother Watching you" (Orwell,2012, p.2) demonstrating the authoritarian regime that controls the individuals. Margaret Atwood's fiction also seems to "imagines a late 20th century future where a woman's ability to procreate is of paramount importance since disease and pollution have led to a catastrophic decline in the birthrate". (Ketter,1989, p.209) Anthony Burgess' A Clockwork Orange is a dark tale about a grim England that offers to change behavior of individuals through controlled rehabilitation centers. Dystopian science fiction as a genre emerges with a slight difference. It usually shows the world being attacked by a 
virus, technology, and aliens from the outer space. Aldous Huxley's Brave New World (1932) is a dystopian science fiction that depicts an engineered system that manipulates reproductive process and marking territorial hierarchies based on social status and intelligence. Fahrenheit 451 (1953) by Ray Bradbury (dystopian science fiction) expresses the apprehension of the world's worst fear of influencing the people through books. The novel We (1920) by Yevgany Zamyatin throws open a world with a panoptical mass surveillance that controls the society. Thus, the dystopian novels of the few that are mentioned here represent a worse in future time. The world as we know might one-day cease to exist and we might find ourselves in the hands of man-made devices or systems.

The terrifying factor is the possibility of a doomsday in the future similar to the fictional representation. Fiction which is identified as dystopian, 'speculates' a dangerous and a disruptive future that undermines the rosy picture of the time in the future'. The above works depict a world in future and presents a new but strange environment for the characters have to endure to represent a harsh and unimaginable ordeal.

But what if the dystopian fiction does not suggest a grim future but a dismal and dark present? Upamanyu Chatterjee's fiction uses a similar approach to narrate stories about human beings who are placed in a bleak environment in the present. In Chatterjee's fiction, dystopia emerges as a unique tactic to subvert the 'ideal'. The novels do not seem to compromise and draw a middle path where the future is depicted as dystopian. the impact of a totalitarian world. Power is often found to be used to gain control over the citizens of state. 1984's Big Brother, or Panopticism in We is unavailable in Chatterjee's novels. There are systems in small pockets that control the characters' mind. However, novels of Upamanyu Chatterjee share an air of despair and a quality that holds the bleakness till the end of the novels. Perhaps the controlling agents have done their deed already. Therefore, there is gloom. Yet, there is an undying influence dystopia hovering over the characters in the novels.

The controlling elements that are present in Chatterjee's fiction are not clearly visible to the naked eye. It is in the beginnings of the narrative itself that a dismal quality is assured. One can only hope for the extent of disappointment to end in the novel. The beginning of the novels creates a sense of despair. For instance, English August (1988), "Through the windshield they watched the silent road, so well-lit and dead.", (Chatterjee, 1988, p.1) Similarly, The Last Burden (1997), begins: "For four slow and secret days, Jamun reads Robert Payne's life of Mahatma Gandhi, while outside August slips into a closed and equally febrile September. The on-off rains are warm, troubled, and touch off a dreary ache in the small of the back and a flame beneath the skin". (Chatterjee,1997, p.3) The Mammaries of the Welfare State (2000), opens with, "Agastya was so enervated by his life in the city that ever so often, when he was alone, he found himself leaning back in his desk chair or resting his head against the armrest of the lumpy sofa in his office that served as his bed, shutting his eyes weeping silently." (Chatterjee, 2000, p.3) The gloomy Weight Loss (2007) also begins on similar lines, "Only when you die will you cease to feel ridiculous, announced Anthony the Physical Education teacher, swaying gracefully on the balls of his feet, rapping his baton against his thigh." (Chatterjee, 2007, p.3) The endings come across as disintegrated as the beginning. In totality, the novels combine the darkest spaces in the world that have characters finding their ways of coping with the situation. It is noteworthy that in The Last Burden the ceiling fan is viewed as an omniscient observer of Jamun's failure. It can be concluded that there is a potent influence of the narrative on the drawing of characters as they are described in the novels.

Decadence and deterioration can be extrapolated to the description of sexual perversion, corruption, boredom/ennui. Agastya, in English August is close to losing sanity because of the boredom that is thrust upon him to endure. It is the narrative that makes the journey of the characters purposeless and miserable. The administration comes across as a powerless structure. Yet it yields power. It is in the failure of the administration that makes Madna an alien site for Agastya. Ironically, the failure yields influence in destroying the present, only to suggest an absence of a utopian future. In The Last Burden, the failure is visible in the degenerative and unsuccessful relationships of the family. Conflicts of the older generation and the new is steeped in older and 'outdated' principles, with arguments over money, house, and relationships with each other. The overbearing parents and their disgruntlements over their sons' lives is daunting and is clearly pointed towards the degenerated idealism of Shyamanand and Urmila that Chatterjee highlights as opposed to the 'ideal' joint family in India. There is lack of idealism, as there is no room for the characters to imagine. Imagination is the key for a future. To think of an ideal, being creative and painting an alternative possibility is necessary. Thomas More must have created the place 'Utopia' only to give an alternative perspective which was necessary for that period. But Chatterjee's fiction does not intend to achieve any alternative perspective. Dystopia hovers around the narrative. It seems to be the only available rationale behind the narratives filled with disillusionment, alienation, and deterioration. 
The elements of decadent behavior and life choices of the characters form a unique blend of strangeness, yet significant, traumatic exchange of abuse between the self and the others. For Agastya, Marcus Aurelius' works become a way of nurturing idealism, how to discipline oneself and remain untouched by the outside world. Ironically, Agastya makes a habit of the meaningless activity of pleasuring himself. Yet, the need to be idealistic does not cease in any protagonist despite the portrayal of being lesser than perfect with their inadequacies such as drugs and sex. Jamun in The Last Burden, is filled with drudgery. He is uncomfortable about his mother Urmila, whining and ranting, but he himself is raving within for he wants to escape. Where he wants to escape to is unclear. However, his thought of escape itself directs us to interpret his hidden idealism. Chatterjee's fiction portrays dystopia through the characters' inadequacies, which is a way to undo the very existence of a Utopia. Therefore, the narrative becomes a superior entity that narrates stories of characters that do not change or even show signs of transformation. Even if they want to seek a change, they are made to witness their end. Bhola involves himself with several partners and seeks the momentary sense of being alive only to end his life at the end of the novel.

Perhaps the unpleasantness and frustrations of the present drive the writers to visualize a temporary dystopian fantasy that allows itself to remain in the future. But Chatterjee's fiction comprises characters who rely on Marijuana, and sex to survive as robots. I would like to use the term robots here, only to suggest that there is no sign of recognizing life in its basic form. They remain as rugged and filled with drudgery as at the beginning. They are run not by a software but are coerced by the chemical reaction because of drugs and erotic pleasure through sex or even through fantasizing about a person. This becomes the means to deal with the dystopian world.

Jamun is neither interested in running away from the family feuds nor is he willing to reduce friction. Being flaccid throughout helps Jamun be a distant witness to the family's feud. Interestingly, the narrative revolves around a passive narration of the boring and uncomfortable story of the family that is least interested in solving their issues. Jamun and Burfi do not want to feel any emotion. They become robotic in this manner. Bhola is a sex robot. He feels nothing after a point. Passion to feel persists but at the cost of his own life. It is not far that we witness Bhola's erotic fantasies consume his own life. Sex finally claims his life. The authority is in the sexual fantasies and his invariable complicated association with his own body and mind. He represents failed young men.

The act of subversion is crucial as it opens spaces for interpretation. More importantly, it widens the prospects of arguing for a grim reality that is daunting but speaks of the ground 'reality'. It may appear 'absurd' but when close attention is paid to the intricate workings of sexually perverted characterization and their unabashed behaviors, follies as humans emerge along with the concept of nothingness. The burden of proof is on the narrative as each protagonist encounters the metaphor of a gigantic hole in their lives. Nothing seems of interest to them. Chatterjee's fiction thus makes a case for a 'present' dystopian reality. The Mammaries of the Welfare State brings to light the eccentricities of the system sprinkled generously with corruption of the mind and body. Bhupen Raghupati, the administration officer displays a heightened version of a sexual predator. His misuse of power and time to consider the welfare of people is lost in a ridiculous game of Love-Like-Hate-Adore. Chatterjee's narrator Agastya, observes this as, "Love-Like-Hate-Adore isn't well-known a game as it should be. It is a splendid timekiller because while squandering away one's most precious resource, it permits one at the same time to move from one object of one's lust to another to gauge whetherand to what extent-they reciprocate one's affections-and indeed, deep in one's heart, what one oneself truly feels for them." (Chatterjee, 2001, p. 45)

Reasoning out, exercising, making efforts to breathe and feel normal are a part of the learning that Agastya has to endure. Agastya's ordeal in Madna and episodes of odd thinking between the shifts emerge as a core factor for Chatterjee's dystopian world. Grim reality remains statuesque. Agatsya seems to be more observant as he gains experience in the corrupt system. His adapting to the bureaucracy perhaps opens him up to newer corrupt practices, but he remains as perplexed as he was in the beginning of his training years. The subversion is in the refusal to change. Chatterjee's fiction is concerned with the present and not of the future. The present is overtly and unabashedly filled with drudgery and disappointments. The characters are clueless about what they endure. This brings us to another interesting experience, which is alienation. One might ask whether it is deliberate or is it a mere a consequence of the dystopian world. I would like to consider the latter as an answer to the question. The excessive desire to sweat and the desire to feel alive expresses the fear of getting estranged from oneself amidst the lying, and escaping from actual conversations. It is here that subversion comes alive fully. The motion of lust and suffering resembles a gyre like motion where it is difficult to point out the beginning or an end to the protagonist's journey of life. As Bede Scott cleverly mentions the absence of plot, especially in English August, he finds himself articulating one reason for the absurdity in the novels. He precariously submits the illogical nature of 
the narratives and says that the plotless is a mark of the mechanical and dry procedures of the Civil Administration office. The monotonous nature of bureaucracy contributes to 'meaninglessness' in the narrative. Therefore, looking for the plot, perhaps, is to embark upon a journey that is aimless. Peter Brooks in his work confirms that as readers we expect something incredible or even witness the journey from one point to another in the novels. (Scott, 510) Bede Scott discusses the very nature of English August that does not allow the reader to foresee a future or even help in creating a new world that ends with a warning and eventually interpreted as a lesson for the future. Alienation plays an important role in the dissipation of meaning and purpose. Therefore, there is a constant seeking of companionship of the self and abusing it with masturbation, sexual fantasies and drugs. These become a part of the world. However, they are also clearly a voice of the dystopian fictional world. They illuminate the darker side of humankind that allows itself to be expressed in loneliness and estrangement. Perhaps it is because of alienation that the characters can observe the external world without a sense of wonder or bewilderment. As Martin Hiedeggar notes, this feeling of boredom creates a distance between the outer and inner world. It also “deintensifies lives.” (Bede Scott, 2012, p. 512)

Bede Scott's efforts in making sense of the 'senseless' become clear when he is convinced of the aim of the narrative itself, where it does not want anyone to think of a significance at all. Scott says, the "crisis of meaning" and "disruption of desire" draws the narrative to a point of destruction. But significantly, the leakage of the collapse "threatens to undermine" the narrative's strength (with Chatterjee's fiction it is the plot) So, it dissipates somewhere and the readers lose all sense of hope, and this is where a subversion of the ideal takes place. The ideal of a perfect story, or a story in the future that ends with a warning, disappears into thin air. Perhaps it is more appropriate if we conclude that there is no hope from the beginning and the story had the least intention of having a typical end to the novel, like other dystopian novels.

\section{CONCLUSION}

Upamanyu Chatterjee's fiction appears dystopian with the forceful presence of decadence, degeneration, and alienation. However, one cannot assess and analyze the author's intention in creating a dystopia. The absence of future and a warning gives a twist to the genre that has been often used to depict a dangerous world that lies ahead. The form is devised to represent a world filled with people who would have a humanitarian vision when inventing a new technology or a system. Lyman Tower
Sargent, one of the foremost critics on utopia, states that utopian literature may have a didactic tendency, but stating that all dystopias have a strong characteristic of issuing a warning at the end of the narrative is definitely problematic. (Sargent L.T, 1994, p. 7) This is because marking a clear boundary to reveal the exact intention of the author would be preposterous in the study of dystopian literature. Chatterjee's fiction, as mentioned above, may have dystopian representations, but we do not know about/of the intention of the author in its entirety. One can only view his works with new perspectives. The understanding of the author's intention may not be possible, but we can safely point out that the dystopian vision in Chatterjee's novels is unlike other dystopian fictions.

\section{REFERENCES}

[1] Chatterjee, U.(1988). English August: An Indian Story. Penguin Books Ltd

[2] ---(1997). The Last Burden. Penguin Books Ltd.

[3] ---(2000). The Mammaries of the Welfare State. Penguin Books India.

[4] --- (2007). Weight Loss. Penguin Books Ltd.

[5] Dvorak, M. (1999). Subverting Utopia: Ambiguity in The Handmaid's Tale. Lire Margaret Atwood: The Handmaid's Tale, Pp 73-86, Open Edition Books 2016, 73-86. https://doi.org/10.4159/9780674028456

[6] Ketterer, D. (1989). Margaret Atwood's" The Handmaid's Tale": A Contextual Dystopia (" La servante écarlate" de Margaret Atwood: une dystopie contextuelle). Science Fiction Studies, 209-217.

[7] Orwell, G. (2021). Nineteen eighty-four. Oxford University Press.

[8] Scott, B. (2012). Reading the Uninteresting: Upamanyu Chatterjee's English, August: An Indian Story. Comparative Literature,53(2012),493-516. https://doi.org/10.1353/cli.2012.0028

[9] Tower Sargent, L. (1994). The Three Faces Of Utopianism Revisited. Utopian Studies, 5(1), 1-37. https://www.jstor.org/stable/2071924 